\title{
Citizens in the Lab: Performance and Validation of eDNA Results
}

\author{
ANDERS P. TØTTRUP $\mathbb{D}$ \\ LEA SVENNINGSEN
}

MARIA RYTTER

MARIE RATHCKE LILLEMARK

PETER MøLLER (D)

STEEN WILHELM KNUDSEN (D)

*Author affiliations can be found in the back matter of this article
CORRESPONDING AUTHOR:

\section{Anders P. Tøttrup}

Natural History Museum of Denmark, University of Copenhagen, DK

aptottrup@snm.ku.dk

KEYWORDS:

citizen science; data credibility; eDNA; monitoring; marine species

\section{TO CITE THIS ARTICLE:}

Tøttrup, AP, Svenningsen, L, Rytter, M, Lillemark, MR, Møller, P, Knudsen, SW. 2021. Citizens in the Lab: Performance and Validation of eDNA Results. Citizen Science: Theory and Practice, 6(1): 35, pp. 1-12. DOI: https://doi.org/10.5334/cstp.382 


\section{INTRODUCTION}

Citizen Science (CS) approaches in biodiversity research offer the potential for large-scale and long-term data collection, which can contribute to population monitoring, species distribution mapping, and conservation policies, as well as including an educational benefit for the volunteers. Application of, and interest in, citizen science has over the past two decades grown exponentially (Kullenberg and Kasperowski 2016; Sandahl and Tøttrup 2020), and citizens typically engage in activities such as 1) data collection, 2) data processing, 3) curriculum-based participation, and 4) community science, the classification types not being mutually exclusive (Bonney et al. 2016). However, involving citizens in several steps of the scientific process remains in its infancy.

A novel non-invasive way of evaluating species diversity in different biomes that is reliant on relatively large datasets and exhaustive sampling is monitoring by environmental DNA (eDNA) (Beng and Corlett 2020; Goldberg et al. 2016; Thomsen and Willerslev 2015) that involves detection of genetic material shed by living organisms to their surrounding habitat. Monitoring of eDNA in water samples is less dependent on taxonomical expertise (Bohmann et al. 2014; Thomsen and Willerslev 2015), and sample collection is reasonably straightforward and can be performed with very little training, which makes the approach a suitable method for a CS setup. Monitoring of eDNA can be done either by detection of single species using a quantitative polymerase chain reaction (i.e., $9 P C R$ ) (Agersnap et al. 2017; Biggs et al. 2015) or by a metabarcoding approach targeting a broader diversity within a limited taxonomical group, e.g., bony fishes (Thomsen et al. 2016; Sigsgaard et al. 2017). The species-specific approach initially had a focus on freshwater species (Biggs et al. 2015; Sigsgaard et al. 2015; Thomsen et al. 2012), but there is a growing body of studies focusing on marine eDNA (Jensen et al. 2018, Knudsen et al. 2019; Garlapati et al. 2019). With an increase in the number of eDNA studies (Tsuji et al. 2019), and a desire to attain larger datasets for eDNA monitoring of biodiversity, a consequential and interesting next step is to apply CS in eDNA monitoring. Although it can be argued to be more precise when carried out by trained laboratorial staff, we opted for a citizen-involved laboratory approach as it gives a unique and exciting hands-on experience, that increases awareness of monitoring biodiversity.

Coupling CS with eDNA monitoring has previously been attempted (Biggs et al. 2015; Buxton et al. 2018; Larson et al. 2017), but these studies involved the participants only in the sampling, not in the subsequent laboratory analysis.

Although CS facilitates the collection of larger datasets, concerns regarding the data quality have been raised
(Burgess et al. 2017). Typically, sound design and volunteer training have been mentioned as essential to secure data quality (Bonney et al. 2014). In cases in which volunteers are conducting similar work as professionals, dataquality assessments should be performed for the data to be scientifically robust (Castagneyrol et al. 2020). Still, scientists have been found to ascribe lower credibility to data collected by younger CS volunteers, indicating a preference for using data collected by college students or older (Burgess et al. 2017). Whether the eDNA monitoring is performed by trained researchers or untrained students, there is an inherent risk of obtaining false-positive or falsenegative detections. For eDNA monitoring, this is either a suspicion that a species is present when it is in fact absent (i.e., false positive) in the aquatic habitat, or the reversethat the eDNA monitoring suggests the species is absent when it is in fact present (i.e., false negative). False- positive/ negative detections in eDNA monitoring usually arise from cross contamination of samples with DNA not originally stemming from the sample or by confusing samples. Both can happen in the laboratory as well as in the field. The consequences of erroneous evaluations based on falsepositive and/or -negative detections can be dire, especially when monitoring introduced species (Jerde et al. 2013). Plans involving eradication of introduced species can be costly and have negative impacts to the environment associated, and if based on incorrect premises of falsepositive detections, be a saddening affair. Similar, rare, and threatened species can be overlooked if a large proportion of samples are falsely evaluated as negative when the rare species in fact was present. In such cases, this can lead to a failure in taking the necessary conservation measurement precautions in time to avoid eradication of threatened species. To avoid this problem, it is important that a CSbased eDNA monitoring approach take into consideration the risk of obtaining false-positive and/ or -negative detections. One important step to minimize the risk of getting false-positive and/or false-negative detections is to include multiple positive and negative controls-that is, control samples that are known to return either positive and/or negative eDNA detection in previous laboratorial set ups. Inclusion of such control samples for each individual preparation of mix of reagents used for eDNA detection will help reduce the risk of getting false-positive and/or -negative detections, and will help avoid many incorrect conclusions being drawn on incorrect premises.

In this paper, we present a project involving citizens in fieldwork sampling as well as in the following advanced laboratory analyses. We also assess the quality of the resulting data by direct comparison with a trained researcher as well as species occurrence data. To avoid the risk of getting false-positive and/or -negative detections, 
we also ensure that the laboratorial work performed has an adequate number of control samples, specifically to avoid drawing wrong conclusions from the data obtained.

\section{METHODS AND MATERIALS}

This study builds on a project called "DNA \& Liv" (abbreviated 'DL') offered to Danish high school students by the Natural History Museum of Denmark. The collection of eDNA samples and analysis of samples was performed by the participants (i.e., the high-school students) who collected samples from the years 2017 and 2018-resulting in a total of 47 unique samples (Figure 1).

Figure 2 illustrates an overall schematic process diagram of the project, where the collaboration and contribution of both citizens and researchers are highlighted.

\section{EXPERIMENTAL DESIGN}

The teaching programme was designed to incorporate citizens in the scientific research process, facilitating handson experiences by testing eDNA assays for environmental

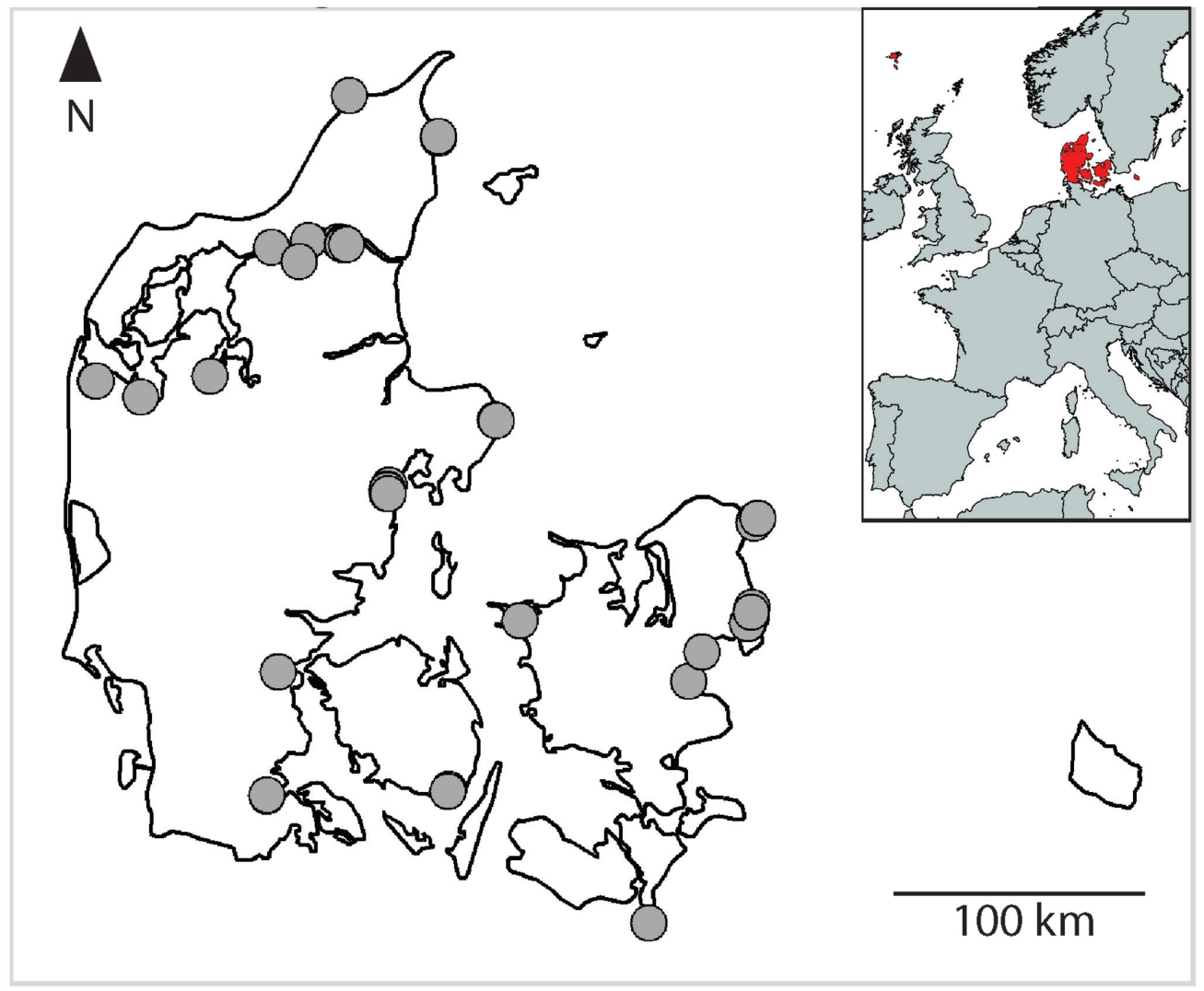

Figure 1 Geographical distribution across Denmark of the 47 analyzed marine samples from 2017-2018. Many samples overlap, explaining the limited number of sampling sites plotted.

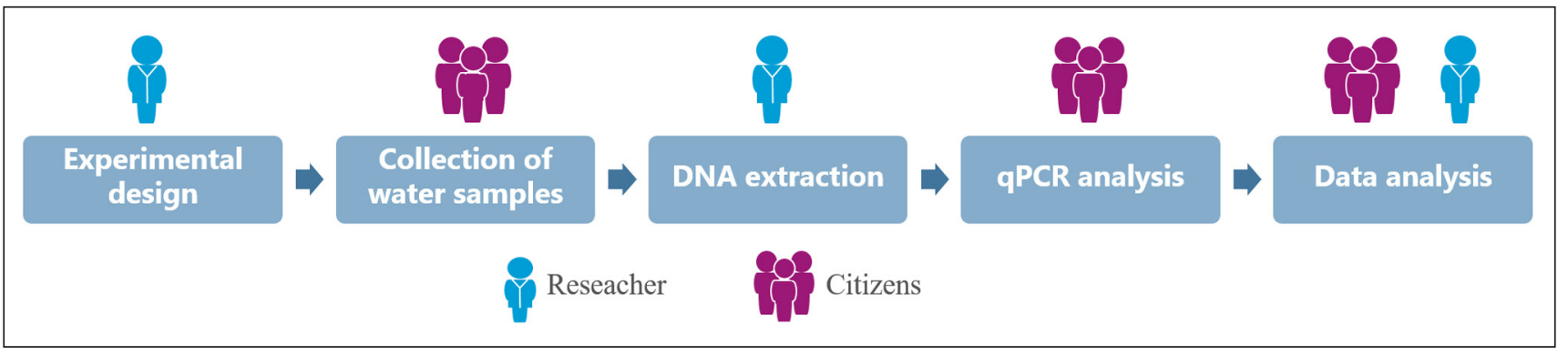

Figure 2 Schematic overview of the project "DNA \& Liv" (abbreviated DL) offered by the Natural History Museum of Denmark as a teaching programme for high school students. The figure icons above the boxes illustrate which parts of the process were conducted by a researcher or by citizens, respectively. 
monitoring of both fresh and marine organisms in Denmark. The study design was undertaken by the researchers to ensure that the project addressed specific, unanswered research questions, and was based on already developed and tested species-specific assays (Andersen et al. 2018; Knudsen et al. 2019; Spens et al. 2017), (Table A in Supplemental File 1).

\section{Collection of water samples}

Field kits, which contained materials and instructions on how to collect and handle the eDNA samples correctly, were shipped to the participants. The collection of eDNA from water samples was performed at local marine environments chosen by the citizens. In 2017, the eDNA samples were collected from July to September, and in 2018, the samples were collected from August to December. eDNA sampling was conducted by filtering water using a Sterivex Filter Unit (Merck Millipore) following past protocols (Agersnap et al., 2017; Spens et al., 2017) with the addition of $96 \%$ ethanol to filters for preservation (Appendix A in Supplemental File 2).

\section{DNA extraction}

The ethanol-fixed Sterivex filters were shipped to Natural History Museum of Denmark and stored at $-18^{\circ} \mathrm{C}$ until DNA extraction (Appendix A in Supplemental File 2). The extraction of eDNA from filtered samples was performed by a researcher because it is mostly a time-consuming process fitting less well with citizen involvement compared with setting up qPCR analysis for detection of eDNA in the extracted filtered samples. Extractions from filters followed protocols presented in past eDNA studies (Thomsen et al. 2016; Sigsgaard et al. 2016; Spens et al 2017). After the eDNA was extracted from the filter units, the sample was stored at $-18^{\circ} \mathrm{C}$ and thawed the same day that the eDNA sample was to be analyzed via $\mathrm{qPCR}$ at the DNA research laboratory.

\section{Training citizens to work in the lab}

Our project included both theoretical and practical training of the participants. A full-day program was scheduled in our DNA laboratory, which is a workspace that can fully accommodate up to 24 people working simultaneously at individual working stations that contain micropipettes, small tabletop centrifuges for $1.5 \mathrm{~mL}$ and $2.0 \mathrm{~mL}$ tubes, and additional required equipment (See Figure 3).

First, participants were given an introduction to the aspects of working with eDNA, qPCR, and molecular methods including species-specific primers and probes as well as instructions on how to prepare and interpret a qPCR analysis. Second, they were trained in how to work sterile, to avoid cross-contamination of samples, and

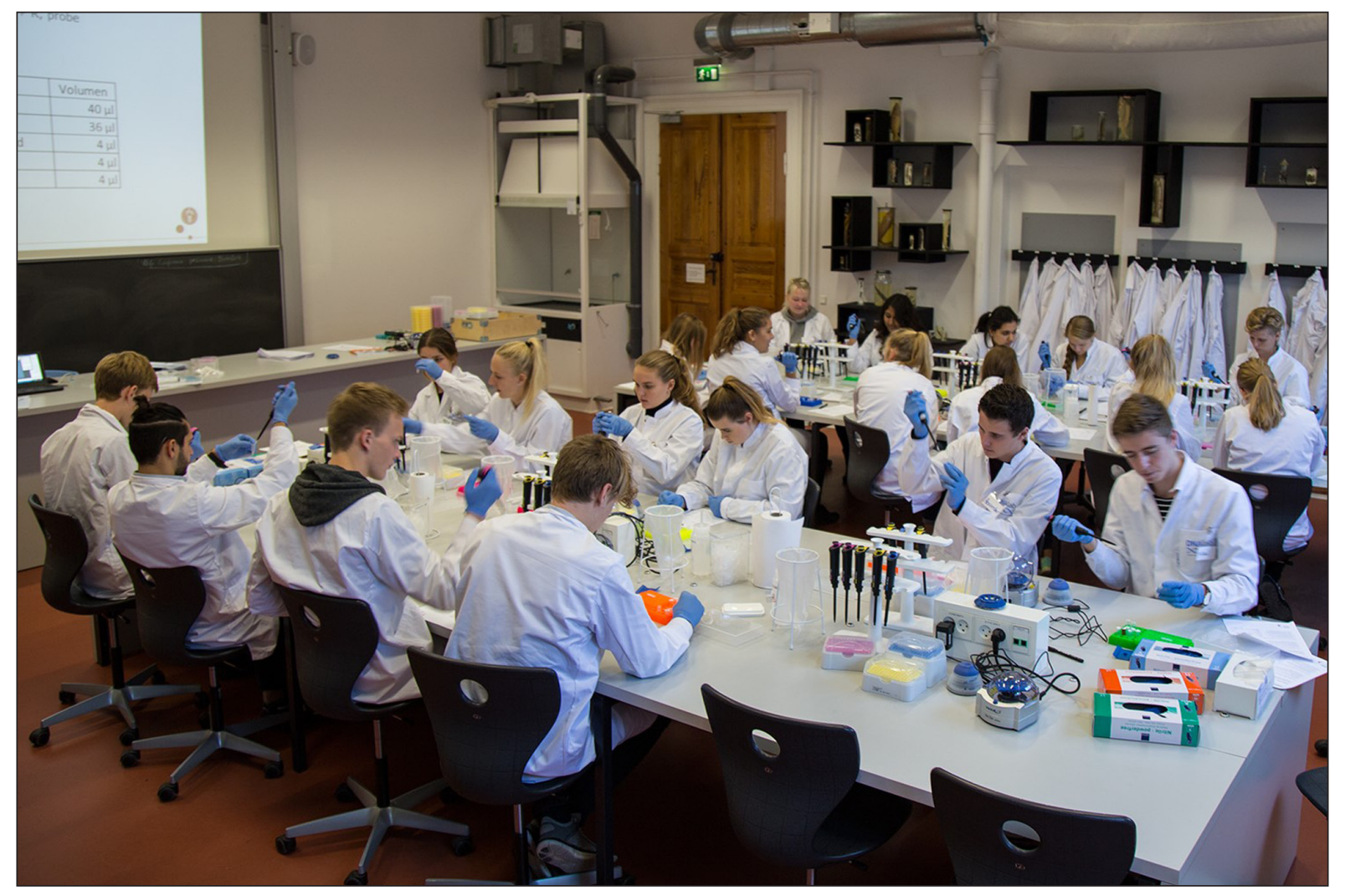

Figure 3 Citizens at work in the DNA laboratory, working with eDNA samples and analyses, October 2015. Photo by Anders P. Schultz. 
to handle a micropipette. After completing this training, participants were asked to commence their eDNA analysis following a written GPCR analysis protocol (Field protocol and QPCR protocol hand-outs in Supplemental Files 3 and 4 , respectively). After having prepared the GPCR analyses (Figure 4a), the PCR tubes were placed in the $\mathrm{PPCR}$ machine. The program for the GPCR machine ran for 2 hours and 9 minutes.

When the GPCR program was finished, the citizens were able to see their individual results on amplification plots (Figure $4 b$ ). The academic staff and the participants did the interpretation of the plots together, and the citizens validated each analysis to confirm whether the analysis was able to detect eDNA from the specific species in the given eDNA sample.

\section{qPCR analysis}

Each species-specific qPCR analysis consisted of four tubes, each with a different specific DNA template added per set of four. (Appendix A in Supplemental File 2). The protocols for volumes and concentrations of reagents follow what has been used in previous studies (Agersnap et al. 2016; Knudsen et al. 2019) using qPCR for monitoring eDNA. We deviated slightly from these past protocols (Field protocol and qPCR protocol hand-outs in Supplemental Files 3 and 4 , respectively) as we omitted the standard dilution series, and opted for screening of multiple species with two out of four tubes allocated for control test. These DNA templates consisted of a positive control sample, a negative control sample with only double-distilled sterile water, and two tubes with added extracted eDNA stemming from the water sample (Figure 4a). Contrary to more traditional qPCR analysis, a standard dilution series was omitted from the setup, as this would have required a dilution series to be included for each species. This was not possible when multiple different species were to be monitored simultaneously in the same qPCR setup, with only four tubes allocated per species assay in the GPCR machine. The decision to monitor multiple species in parallel instead of focusing on just one species per qPCR run was made to allow citizens to witness at least a couple of positive detections from their own water samples. A qPCR run with only a single species assay would have allowed for the inclusion of a standard dilution series, but would for the very rare and infrequent species equal a large proportion of detection attempts being negative, which would have been disheartening for the citizen, and their experience would be more positive with at least a couple of positive detections.

\section{Data analysis}

The positive and negative control tests ensured that the performance of citizens' abilities with laboratory

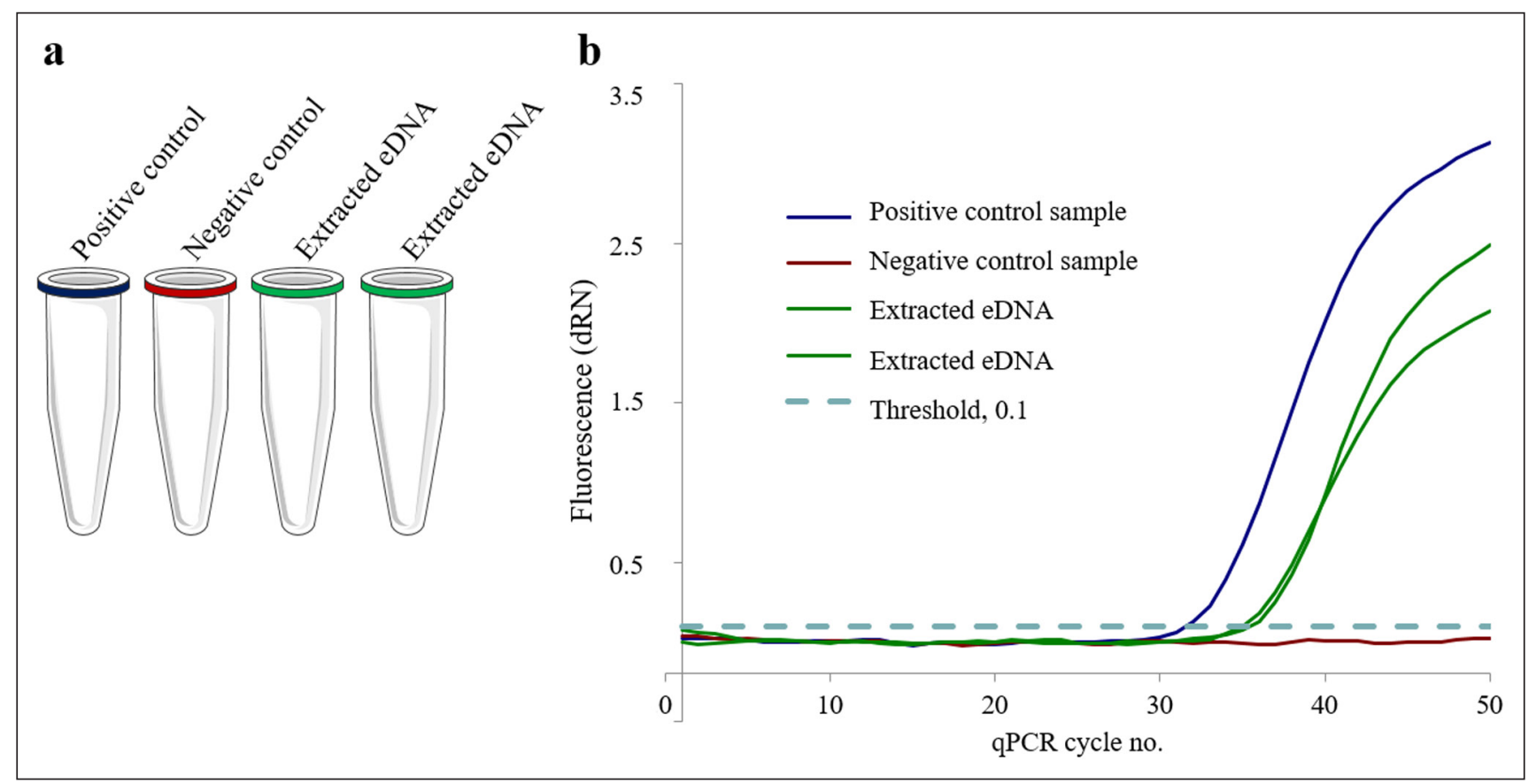

Figure 4 Each species-specific qPCR analysis consisted of four tubes. Along with qPCR reagents, negative and positive control samples were added to the tubes with extracted eDNA obtained from filters. The positive control sample (blue) is a purified and diluted target DNA molecule initially obtained from the target species. The negative control sample (red) is double-distilled sterile water. The eDNA sample (green) is extracted DNA from the filter unit (a). The sigmoid amplification plot obtained from the PCR reaction (b) is a typical diagram and result of a QPCR assay. The increase in relative fluorescence levels reflects a higher number of DNA molecules present in the reaction tube for each cycle of amplification in the qPCR. 
eDNA work could be evaluated. The citizens' tests were compared with similar tests conducted by an established researcher within the eDNA field, and tests for statistically significant differences were conducted using the Chisquare test. This comparison was carried out for 14 of the 16 species assays, as two of the assays in the project were discarded because the researcher did not analyze these two assays. Each citizen scientist included a positive and a negative control sample for each of the two replicates of eDNA from their single water sample. The control tests were included to eliminate false-positive detection. The number of tests between the citizens and the researcher is not directly comparable, as the qPCR setup prepared by the researcher involved several positive controls in various concentrations. To minimize the risk of interpreting false positives, an increase in amplification signals after PCR cycle 41 and below a relative fluorescence threshold of 0.1 was disregarded; this applied to the setup performed by the researcher and by the citizens.

\section{MAPPING STUDY OF EDNA FROM ROUND GOBY AND ATLANTIC COD}

To assess the resulting data produced by the citizens, we mapped the results inferred for eDNA detection of two fish species and compared this with validated mappings in a national database, Fish Atlas (www.fiskeatlas.dk). The two species were the round goby (Neogobius melanostomus) and the Atlantic cod (Gadus morhua). The round goby was selected because it is a non-indigenous species to the Danish marine environment that is currently observed in the southeastern part of Danish seas (Azour et al. 2015;
Nurkse et al. 2018). The round goby is suspected to have an extensive effect on the ecosystems due to competition with native species for food (Almqvist et al. 2010) and perhaps breeding and shelter grounds (Janssen and Jude 2001). With its considerable dispersal ability, the round goby has become one of the most significant non-indigenous species in Danish waters (EPA 2017). The Atlantic cod was included because it is widely distributed and is a wellknown commercial species in the Danish waters. It is one of the few commercial marine fishes that tolerate brackish waters, and they are found far into the Baltic Sea (Heesen et al. 2015). In recent years, however, stocks are suffering from environmental stress (Limburg and Casini 2019) and overfishing, leaving fishermen and managers in great despair (Jonzén et al. 2002).

\section{RESULTS}

In total, the citizens looked for 16 different marine animal species' eDNA in each of the 47 water samples. Figure 5 illustrates the citizens' average success rate per species assay, where the success rate is defined as passing both the negative and positive control test. The success rate of the citizens was above $60 \%$ for all 16 marine species assays, with the average success rate at $72 \%$.

For citizens, 1,249 out of 1,310 negative samples performed as expected, i.e., unable to return amplification ( 95\%), whereas only 989 out of 1,312 ( 75\%) of the positive controls performed as expected, i.e., able to return amplification on added DNA (Figure 6). This indicates that

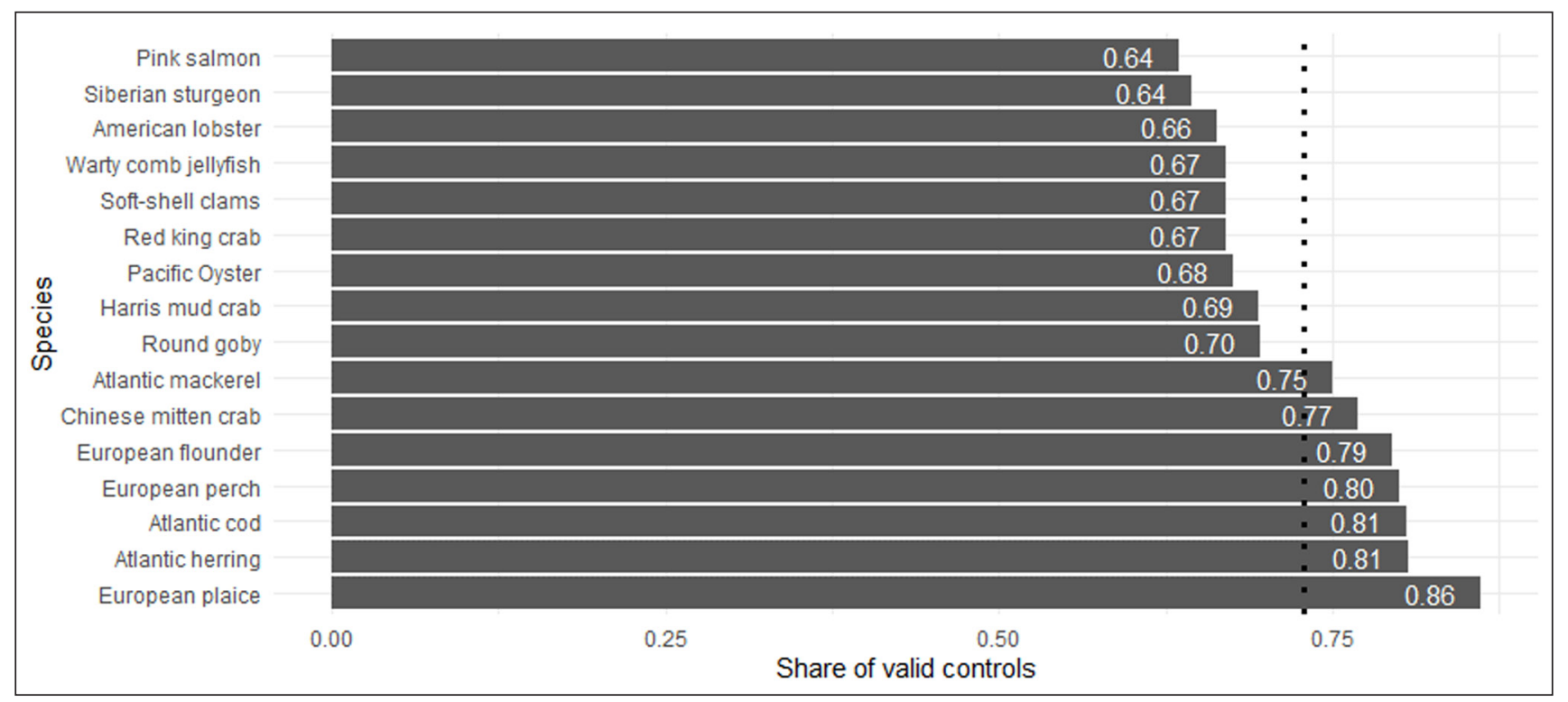

Figure 5 Share of valid controls conducted by citizens per species assay. The average success rate across species, 0.72 , is marked by the dotted line. 


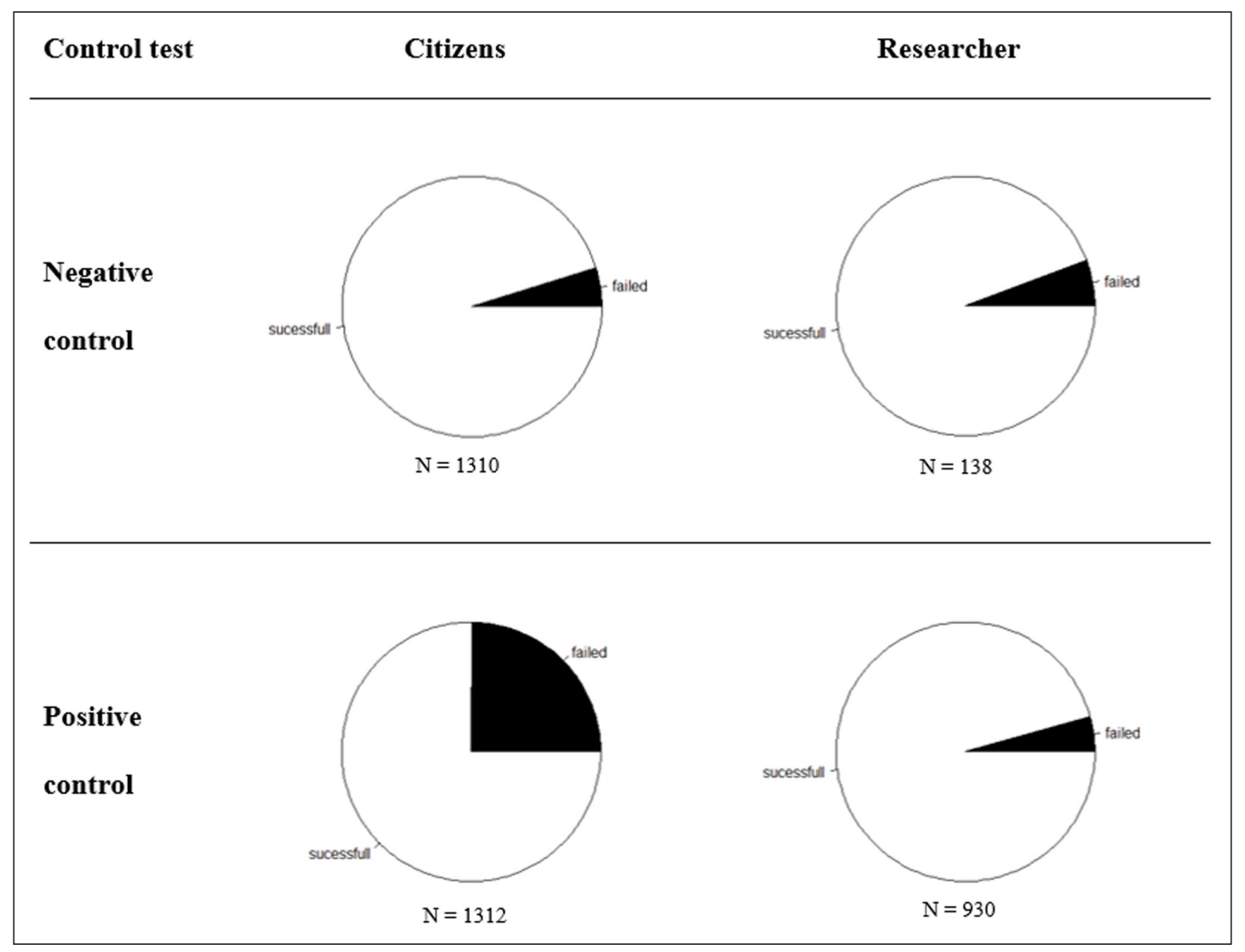

Figure 6 Share of failed and successful control tests for the researcher and citizens pooled across the 14 species assays included in the comparison. See Table 1 for statistical results.

the citizens had more difficulties in performing the positive control, compared with their negative control and also deviates from the performance of the researcher, whose performance is more or less consistent across the two types of control tests (Table 1). For the researcher, 130 of the 138 negative controls performed as expected, returning no amplification ( 94\%), and similarly, 889 of the 930 positive controls performed as expected, able to amplify on DNA added ( 96\%).

Thus, our results indicate that citizens can perform negative control tests with similar quality as a trained researcher. However, for the positive control tests, citizens perform worse than the researcher (Table 1).

\section{MAPPING STUDY OF EDNA FROM ROUND GOBY AND ATLANTIC COD}

Our citizen eDNA results confirm the currently known distribution of round goby and Atlantic cod (Figure 7). The round goby is known only in the southeastern part of the inner Danish seas, matching the presence as inferred in the Fish Atlas except for one sample from northern Denmark, indicating a potential range extension (see Discussion section). The Atlantic cod is found throughout the Danish seas, which matches the broad distribution of this common species inferred from the Fish Atlas project.

\section{DISCUSSION}

In this study, we present the successful involvement of citizens in several parts of the scientific process. The participants collect water samples, conduct advanced laboratory analyses, and interpret results, thus producing data of the same quality as trained researchers. If citizens can perform these tasks, while ensuring a high level of data credibility, their work could be taken directly as a starting point for data analysis that can handle the scrutiny of the peer-reviewed evaluation required for scientific publication. Furthermore, if the combination of CS with species-specific eDNA can be performed with adequate precision, this enables a continuous and broad-scale CSbased biodiversity monitoring for both fresh and marine water environments. Citizen scientist involvement in the lab work has educational and training benefit as well as motivational aspects for scientist to invest their time and efforts in collecting samples. This can contribute to 


\begin{tabular}{lllll}
\hline & RESEARCHER & CITIZENS & $\begin{array}{l}\text { CHI-SQUARED } \\
\text { VALUE }\end{array}$ & $\begin{array}{l}\text { LEVEL OF } \\
\text { SIGNIFICANCE }\end{array}$ \\
\hline $\begin{array}{l}\text { Negative control being } \\
\text { negative as expected/total }\end{array}$ & $130 / 138$ & $1249 / 1310$ & 0.36 & \\
\hline $\begin{array}{l}\text { Positive control being positive } \\
\text { as expected/total }\end{array}$ & $889 / 930$ & $989 / 1312$ & 163.46 & $* *$ \\
\hline Failed negative controls/total & $8 / 138$ & $61 / 1310$ & 0.15 & $* * *$ \\
\hline Failed positive controls/total & $41 / 930$ & $323 / 1312$ & 161.97 & $*$ \\
\hline
\end{tabular}

Table 1 Chi-squared test of difference in proportions of negative and positive control tests, performing as expected and failing to perform as expected, between researcher and citizens.

Note: Significance level: ${ }^{* *} p=0.01,{ }^{* *} p=0.05,{ }^{*} p=0.10$.

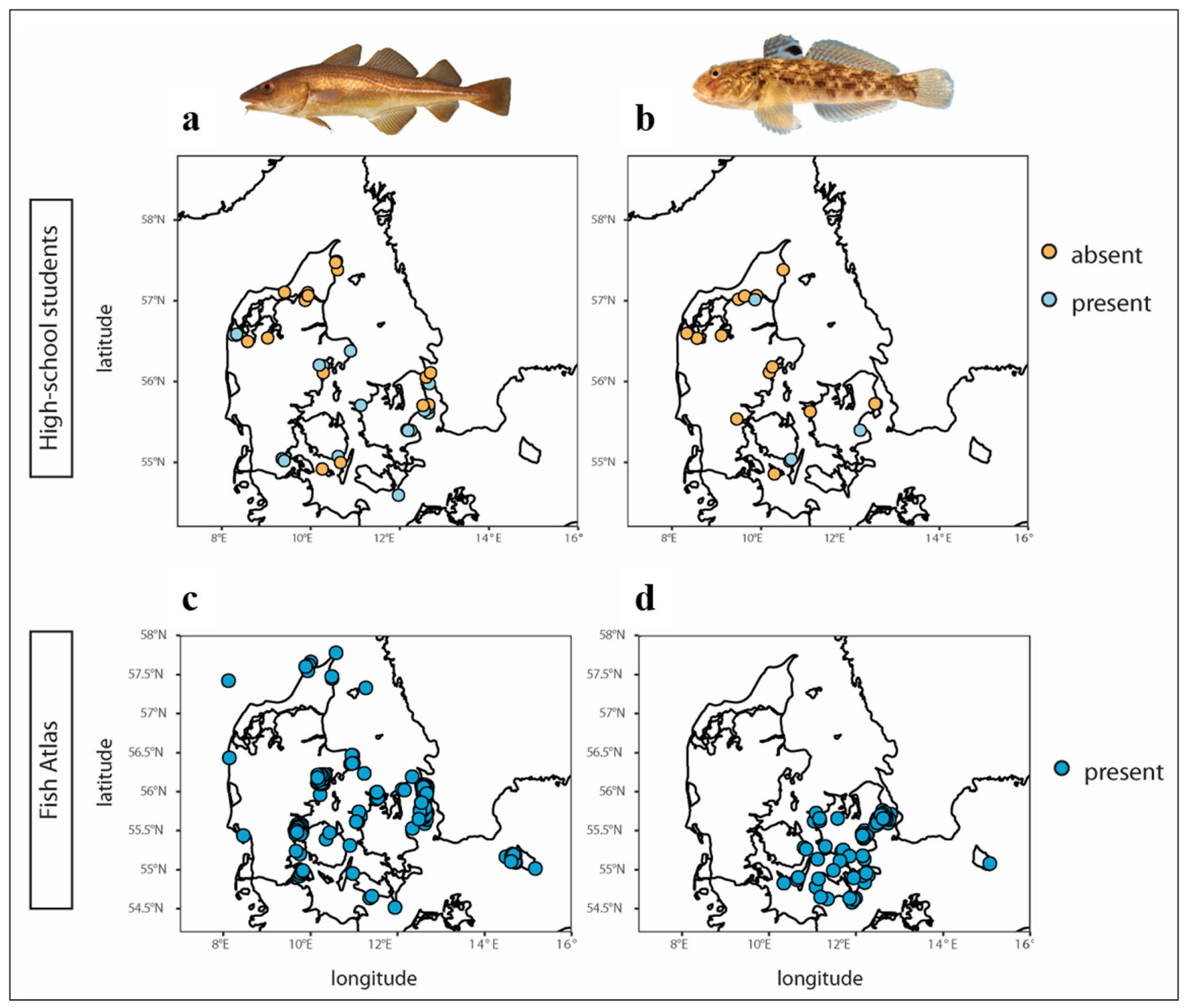

Figure 7 Presence and absence data based on eDNA data for the Atlantic cod (Gadus morhua) (a) and the round goby (Neogobius melanostomus) (b). The presence and absence of the same two species but based on data from the official database, Fish Atlas, for Atlantic cod $(c)$ and the round goby $(d)$. Photo inserts of Atlantic cod $(41 \mathrm{~cm})$ and round goby $(9.9 \mathrm{~cm})$ by Henrik Carl.

the assessment of both non-indigenous and commercial species across a wide geographic area and over time, which again can help when evaluating the environmental status in the aquatic ecosystems.

The inclusion of both positive and negative control samples for each single reagent mix prepared by each student group ensures that false-negative detections play an extremely low role in the data obtained. If one student group were to forget a reagent in their preparation of a mix of reagents, this would lead to no detection of eDNA. The inclusion of positive controls for every single mix prepared avoids this otherwise potentially introduces false negative 
detections in the obtained data. Similarly, the inclusion of negative controls in each single mix and setup prepared by each student group ensures that extracted eDNA from filtered water samples have been added correctly to reaction tubes. If negative controls start detecting eDNA, it is a clear indication that something has been performed incorrectly and that the obtained data should be disregarded. The setup with four reaction tubes per student, where two out of four tubes are assigned as positive and negative controls, ensures that false detections to a large extent can be weeded out of the data sets obtained.

The citizens' positive control tests showed a high success rate but was significantly lower compared with the researchers' positive control tests. This result was expected because the sensitivity in a $\mathrm{GPCR}$ setup usually involves many replicates and inclusion of standard dilution series, which students were not able to perform because it was their first time working with this type of analysis in the lab, and we did not include high concentrations of DNA that can serve as positive controls as this can pose a risk of cross contamination. Also, the standard dilution series was excluded because it would have taken up too many $\mathrm{qPCR}$ reaction wells per analysis, and would have made it complicated to monitor eDNA from many different species in the same single setup. As our study set-up for qPCR analysis of eDNA samples includes only results with control tests performing as expected (i.e., being negative or positive in amplification as respective control indicated), there is a considerable exclusion of false-negative results.

Mapping the eDNA results for the Atlantic cod showed a few absences of eDNA in locations where the official database had registered observations within the same sampling years (Figure 7). This difference can be caused by the preferred habitat choice of the Atlantic cod, the location of the citizens' choice of sampling site, and the one-sample strategy in the project.

The results for round goby indicate that eDNA from this species is present in one water sample collected in the northern part of Denmark (Figure 7), which deviates from the observations in the Fish Atlas. This result is a surprise and a false positive cannot be completely ruled out, but the presence of round goby in this northern location is plausible because the species is currently spreading in Danish waters (Azour et al 2015) and might have reached the area in small numbers.

We were able to generate a mapped distribution of the round goby and the Atlantic cod that is overall similar to the already known distribution of these two species. The maps (Figure 7) support that CS species-specific eDNA monitoring can be used actively in the monitoring of both non-indigenous and commercial species. However, to fully test the scale of potential citizen inclusion in laboratory work, future work should focus on testing the participating citizens' educational background and experience, and assessing whether this influences their ability to perform the laboratory analyses. Another interesting follow-up would be to investigate the effects of previous traininge.g., how the same group of students would perform during a revisit to the lab, and whether there might be an improvement in proportion of failed control tests.

This CS project was also intended to benefit the participants (high school students) by increasing their knowledge of both monitoring species-specific eDNA via a $\mathrm{QPCR}$ setup and the scientific process in general by working with authentic samples and producing data for use in species management (Trumbull et al. 2000). When engaging citizens in a CS project, the practice of learning about the scientific process can be viewed as a core benefit of the project, as the citizens are allowed to engage with authentic data, the research process, and the work involved in answering scientific questions (Edwards et al. 2018). Moreover, the experience of participating in a CS project can ideally increase the citizens' engagement with science and nature, while scientists get more data and the opportunity to increase public knowledge of their research (Harlin et al. 2018). Previous studies using different CS methods have found that the participants appreciate the aspect of real research, and the value of their efforts in contributing to the research (Mitchell et al. 2017; Steinke et al. 2017). Future work should ideally investigate the learning outcomes and experiences of the participants in this relatively new field of combining CS and eDNA approaches.

\section{CONCLUSION}

Our study finds that citizens, after a few hours of training, can successfully work with species-specific GPCR based eDNA analyses and generate validated results useful for monitoring marine species. The accumulated success rate for expected performance of positive and negative control tests reaches a level of $72 \%$. On the basis of citizens' successful control tests, it is possible to examine and rely on the corresponding results of eDNA detection from specific species, as shown for round goby and Atlantic cod.

The described project has promising applications in monitoring of non-indigenous, threatened, or rangerestricted species. It should, however, be emphasized that eDNA monitoring, just like any other method, can be biased by false-positive and false-negative results when performed both by experienced personnel and by citizen scientists. Detailed and careful evaluations should therefore always be performed before eDNA results are used in, for example, eradication campaigns, checklists, or new field guides to certain environments. 


\section{SUPPLEMENTARY FILES}

The supplementary files for this article can be found as follows:

- Supplemental File 1. Table A. DOI: https://doi. org/10.5334/cstp.382.s1

- Supplemental File 2. Appendix A. DOI: https://doi. org/10.5334/cstp.382.s2

- Supplemental File 3. Field protocol handout. DOI: https://doi.org/10.5334/cstp.382.s3

- Supplemental File 4. qPCR protocol handout. DOI: https://doi.org/10.5334/cstp.382.s4

\section{ACKNOWLEDGEMENTS}

We would like to thank all the participants for their willingness to take part in the project. The authors would like to thank Sara Louise Borregaard Larsen, Sarah Isling Pærregaard, and Maja Elling Christensen for their help with DNA extraction, along with Pernille Vibeke Selmer Olsen for her guidance with the laboratory work. Pernille Hjort is thanked for her large contribution in establishing the project, and Henrik Carl is thanked for extracting data from the Danish Fish Atlas database. The project "DNA \& Liv" was supported by the Innovation Fund Denmark (Grant J.nr. 104-2012-1), by the Lundbeck Foundation, and by the Danish Environmental Agency [Miljøstyrelsen].

\section{COMPETING INTERESTS}

The authors have no competing interests to declare.

\section{AUTHOR CONTRIBUTIONS}

A first draft and revisions of the manuscript was prepared by all authors. APT, MR, ML, PRM, and SWK conceived the ideas for the manuscript. Data collection was carried out by ML, MR, and SWK. LSS, SWK, and MR performed the analysis of the data. Students collected the samples and students performed the laboratory analysis of the extracted samples supervised by MR, ML, and SWK. Samples were extracted by laboratory staff.

\section{AUTHOR AFFILIATIONS}

Anders P. Tøttrup (D) orcid.org/0000-0001-8776-9629

Natural History Museum of Denmark, University of Copenhagen, DK Lea Svenningsen

Natural History Museum of Denmark, University of Copenhagen, DK
Maria Rytter

Natural History Museum of Denmark, University of Copenhagen, DK

Marie Rathcke Lillemark

Natural History Museum of Denmark, University of Copenhagen, DK

Peter Møller (D) orcid.org/0000-0002-0177-0977

Natural History Museum of Denmark, University of Copenhagen, DK and Norwegian College of Fishery Science, UiT - The Arctic University of Norway, Tromsø, Norway

Steen Wilhelm Knudsen (D) orcid.org/0000-0003-0428-9940 NIVA Denmark Water Research, Copenhagen, Denmark

\section{REFERENCES}

Agersnap, S, Larsen, WB, Knudsen, SW, Strand, D, Thomsen, PF, Hesselsøe, M, Mortensen, PB, Vrålstad, T and Møller, PR. 2017. Monitoring of noble, signal and narrow-clawed crayfish using environmental DNA from freshwater samples. PLOS ONE, 12(6): e0179261. DOI: https://doi.org/10.1371/journal.pone.0179261

Almqvist, G, Strandmark, AK and Appelberg, M. 2010. Has the invasive round goby caused new links in Baltic food webs? Environmental Biology of Fishes, 89(1): 79-93. DOI: https://doi. org/10.1007/s10641-010-9692-z

Andersen, JH, Kallenbach, E, Thaulow, J, Hesselsøe, M, Bekkevold, D, Hansen, BK, Jacobsen, LMW, Olesen, CA, Møller, PR and Knudsen, SW. 2018. Development of species-specific eDNA-based test systems for monitoring of non-indigenous species in Danish marine waters. In 77. Norsk institutt for vannforskning. www.niva.no.

Azour, F, van Deurs, M, Behrens, J, Carl, H, Hüssy, K, Greisen, K, Ebert, $\mathbf{R}$ and $\mathbf{M} \varnothing l$ ler, PR. 2015. Invasion rate and population characteristics of the round goby Neogobius melanostomus: effects of density and invasion history. Aquatic Biology, 24(1): 41-52. DOI: https://doi.org/10.3354/ab00634

Beng, KC and Corlett, RT. 2020. Applications of environmental DNA (eDNA) in ecology and conservation: opportunities, challenges and prospects. In Biodiversity and Conservation. DOI: https://doi.org/10.1007/s10531-020-01980-0

Biggs, J, Ewald, N, Valentini, A, Gaboriaud, C, Dejean, T, Griffiths, RA, Foster, J, Wilkinson, JW, Arnell, A, Brotherton, P, Williams, $\mathbf{P}$ and Dunn, F. 2015. Using eDNA to develop a national citizen science-based monitoring programme for the great crested newt (Triturus cristatus). Biological Conservation, 183: 19-28. DOI: https://doi.org/10.1016/j.biocon.2014.11.029

Bonney, R, Phillips, TB, Ballard, HL and Enck, JW. 2016. Can citizen science enhance public understanding of science? Public Understanding of Science, 25(1): 2-16. DOI: https://doi. org/10.1177/0963662515607406

Bonney, R, Shirk, JL, Phillips, TB, Wiggins, A, Ballard, HL, MillerRushing, AJ and Parrish, JK. 2014. Next Steps for Citizen Science. Science, 343(6178): 1436 LP - 1437. DOI: https://doi. org/10.1126/science.1251554

Burgess, HK, DeBey, LB, Froehlich, HE, Schmidt, N, Theobald, EJ, Ettinger, AK, HilleRisLambers, J, Tewksbury, J and Parrish, JK. 2017. The science of citizen science: exploring barriers to use as a primary research tool. Biological Conservation, 208: 113-120. DOI: https://doi.org/10.1016/j.biocon.2016.05.014 
Buxton, AS, Groombridge, JJ and Griffiths, RA. 2018. Comparison of two citizen scientist methods for collecting pond water samples for environmental DNA studies. Ctizen Science: Theory and Practice, 3(2): 2. DOI: https://doi.org/10.5334/cstp.151

Castagneyrol, B, Valdés-Correcher, E, Bourdin, A, Barbaro, L, Bouriaud, O, Branco, M, Centenaro, G, Csóka, G, Duduman, M-L and Dulaurent, A-M. 2020. Can school children support ecological research? Lessons from the Oak Bodyguard Citizen Science Project. Citizen Science: Theory and Practice, 5(1). DOI: https://doi.org/10.5334/cstp.267

Edwards, R, Kirn, S, Hillman, T, Kloetzer, L, Mathieson, K, McDonnell, D and Phillips, T. 2018. Learning and developing science capital through citizen science. In Citizen Science: Innovation in Open Science, Society and Policy. UCL Press. DOI: https://doi.org/10.2307/j.ctv550cf2.33

EPA, D. 2017. Handlingsplan mod invasive arter. https://mst. dk/media/143350/handlingsplan_invasive-arter_juni17.pdf. Garlapati, D, Charankumar, B, Ramu, K, Madeswaran, $P$ and Ramana Murthy, MV. 2019. A review on the applications and recent advances in environmental DNA (eDNA) metagenomics. In Reviews in Environmental Science and Biotechnology, 18: 389-411. DOI: https://doi.org/10.1007/s11157-019-09501-4

Goldberg, CS, Turner, CR, Deiner, K, Klymus, KE, Thomsen, PF, Murphy, MA, Spear, SF, McKee, A, Oyler-McCance, SJ, Cornman, RS, Laramie, MB, Mahon, AR, Lance, RF, Pilliod, DS, Strickler, KM, Waits, LP, Fremier, AK, Takahara, T, Herder, JE and Taberlet, P. 2016. Critical considerations for the application of environmental DNA methods to detect aquatic species. Methods in Ecology and Evolution, 7: 1299-1307. DOI: https://doi.org/10.1111/2041-210X.12595

Harlin, J, Kloetzer, L, Patton, D, Leonhard, C and Students L.A.S. high school. 2018. Turning students into citizen scientists. In Citizen Science: Innovation in Open Science, Society and Policy. UCL Press. DOI: https://doi.org/10.2307/j.ctv550cf2.35

Heesen, HJL, Daan, $\mathbf{N}$ and Ellis, JR. 2015. Fish Atlas of the Celtic Sea, North Sea and Baltic Sea: Based on International Research Vessel Data. Wageningen, The Netherlands: Wageningen Academic Publishers. DOI: https://doi.org/10.3920/978-908686-878-0

Janssen, J and Jude, DJ. 2001. Recruitment failure of mottled sculpin Cottus bairdi in Calumet Harbor, southern Lake Michigan, induced by the newly introduced round goby Neogobius melanostomus. Journal of Great Lakes Research, 27(3): 319-328. DOI: https://doi.org/10.1016/S03801330(01)70647-8

Jensen, MR, Sigsgaard, EE, Agersnap, S, Rasmussen, JJ, Baattrup-Pedersen, A, Wiberg-Larsen, P, Thomsen, PF. 2021. Seasonal turnover in community composition of streamassociated macroinvertebrates inferred from freshwater environmental DNA metabarcoding. Environmental DNA, 3: 861-876. DOI: https://doi.org/10.1002/edn3.193

Jerde, CL, Chadderton, WL, Mahon, AR, Renshaw, MA, Corush, J, Budny, ML, Mysorekar, S and Lodge, DM. 2013. Detection of Asian carp DNA as part of a Great Lakes basin-wide surveillance program. Canadian Journal of Fisheries and Aquatic Sciences, 70(4): 522-526. DOI: https://doi.org/10.1139/ cjfas-2012-0478
Jonzén, N, Cardinale, M, Gårdmark, A, Arrhenius, F and Lundberg, P. 2002. Risk of collapse in the eastern Baltic cod fishery. Marine Ecology Progress Series, 240: 225-233. DOI: https://doi.org/10.3354/meps240225

Knudsen, SW, Ebert, RB, Mortensen, PB, Kuntze, F, Hesselsøe, M, Hassingboe, J, Thomsen, PF, Sigsgaard, EE, Egg, E and Møller, PR. 2019. Species-specific detection of six commercially important marine fishes in the Baltic Sea using environmental DNA. Journal of Experimental Marine Biology and Ecology.

Kullenberg, C and Kasperowski, D. 2016. What is citizen science?-A scientometric meta-analysis. PloS One, 11(1): e0147152. DOI: https://doi.org/10.1371/journal. pone.0147152

Larson, ER, Renshaw, MA, Gantz, CA, Umek, J, Chandra, S, Lodge, DM and Egan, SP. 2017. Environmental DNA (eDNA) detects the invasive crayfishes Orconectes rusticus and Pacifastacus leniusculus in large lakes of North America. Hydrobiologia, 800(1): 173-185. DOI: https://doi.org/10.1007/ s10750-017-3210-7

Limburg, KE and Casini, M. 2019. Otolith chemistry indicates recent worsened Baltic cod condition is linked to hypoxia exposure. Biology Letters, 15(12): 20190352. DOI: https://doi. org/10.1098/rsbl.2019.0352

Mitchell, N, Triska, M, Liberatore, A, Ashcroft, L, Weatherill, $\mathbf{R}$ and Longnecker, N. 2017. Benefits and challenges of incorporating citizen science into university education. PLOS ONE, 12(11): e0186285. DOI: https://doi.org/10.1371/journal. pone. 0186285

Nurkse, K, Kotta, J, Rätsep, M, Kotta, I and Kreitsberg, R. 2018. Experimental evaluation of the effects of the novel predators, round goby and mud crab on benthic invertebrates in the Gulf of Riga, Baltic Sea. Journal of the Marine Biological Association of the United Kingdom, 98(1): 25-31. DOI: https://doi. org/10.1017/S0025315417001965

Sandahl, A and Tøttrup, AP. 2020. Marine Citizen Science: Recent Developments and Future Recommendations. Citizen Science: Theory and Practice, 5(1): 24. DOI: https://doi.org/10.5334/ cstp. 270

Sigsgaard, EE, Carl, H, Møller, PR and Thomsen, PF. 2015. Monitoring the near-extinct European weather loach in Denmark based on environmental DNA from water samples. Biological Conservation, 183: 46-52. DOI: https://doi. org/10.1016/j.biocon.2014.11.023

Sigsgaard, EE, Nielsen, IB, Bach, SS, Lorenzen, ED, Robinson, DP, Knudsen, SW, Pedersen, MW, Jaidah, M, Al, Orlando, L, Willerslev, E, Møller, PR and Thomsen, PF. 2017. Population characteristics of a large whale shark aggregation inferred from seawater environmental DNA. Nature Ecology \& Evolution, 1(1): 1-5. DOI: https://doi.org/10.1038/s41559-0160004

Spens, J, Evans, AR, Halfmaerten, D, Knudsen, SW, Sengupta, ME, Mak, SST, Sigsgaard, EE and Hellström, M. 2017. Comparison of capture and storage methods for aqueous macrobial eDNA using an optimized extraction protocol: advantage of enclosed filter. Methods in Ecology and Evolution, 8(5): 635-645. DOI: https://doi.org/10.1111/2041-210X.12683 
Steinke, D, Breton, V, Berzitis, E and Hebert, PDN. 2017. The School Malaise Trap Program: Coupling educational outreach with scientific discovery. PLOS Biology, 15(4): e2001829. DOI: https://doi.org/10.1371/journal.pbio.2001829

Thomsen, PF, Kielgast, J, Iversen, LL, Møller, PR and Rasmussen, M. 2012. Detection of a Diverse Marine Fish Fauna Using Environmental DNA from Seawater Samples. PLOS ONE, 7(8): 41732. DOI: https://doi.org/10.1371/journal. pone.0041732

Thomsen, PF, Møller, PR, Sigsgaard, EE, Knudsen, SW, Jørgensen, OA and Willerslev, E. 2016. Environmental DNA from seawater samples correlate with trawl catches of subarctic, deepwater fishes. PLoS ONE, 11(11). DOI: https://doi. org/10.1371/journal.pone.0165252
Thomsen, PF and Willerslev, E. 2015. Environmental DNA - An emerging tool in conservation for monitoring past and present biodiversity. Biological Conservation, 183: 4-18. DOI: https:// doi.org/10.1016/j.biocon.2014.11.019

Trumbull, DJ, Bonney, R, Bascom, D and Cabral, A. 2000.

Thinking scientifically during participation in a citizenscience project. Science Education, 84(2): 265-275. DOI: https:// doi.org/10.1002/(SICI)1098-237X(200003)84:2<265::AIDSCE7>3.0.CO;2-5

Tsuji, S, Takahara, T, Doi, H, Shibata, N and Yamanaka, H. 2019. The detection of aquatic macroorganisms using environmental DNA analysis-A review of methods for collection, extraction, and detection. Environmental DNA, 1(2): 99-108. DOI: https:// doi.org/10.1002/edn3.21

\section{TO CITE THIS ARTICLE:}

Tøttrup, AP, Svenningsen, L, Rytter, M, Lillemark, MR, Møller, P, Knudsen, SW. 2021. Citizens in the Lab: Performance and Validation of eDNA Results. Citizen Science: Theory and Practice, 6(1): 35, pp. 1-12. DOI: https://doi.org/10.5334/cstp.382

Submitted: 29 December 2020 Accepted: 02 August 2021 Published: 16 December 2021

\section{COPYRIGHT:}

(C) 2021 The Author(s). This is an open-access article distributed under the terms of the Creative Commons Attribution 4.0 International License (CC-BY 4.0), which permits unrestricted use, distribution, and reproduction in any medium, provided the original author and source are credited. See http://creativecommons.org/licenses/by/4.0/.

Citizen Science: Theory and Practice is a peer-reviewed open access journal published by Ubiquity Press.

\section{]u[ $ə$}

